\title{
Integrating telecollaboration for intercultural language acquisition at secondary education: lessons learned
}

\author{
Kristi Jauregi ${ }^{1}$
}

\begin{abstract}
The TILA ${ }^{2}$ project originated from the need to explore whether and how telecollaboration affects language learning processes for communication, intercultural understanding and motivation of youngsters learning foreign languages at secondary schools and to empower teachers to pioneer meaningful pedagogical innovation in the curriculum of foreign languages at secondary schools. In the 2,5 year project, 837 pupils, 300 student teachers and 48 teachers participated in telecollaboration exchanges. The results show that task-based telecollaboration can be successfully integrated in the foreign language curriculum by blending different pedagogical activities. These exchanges can contribute to enhance pupils' communicative competence, intercultural awareness and motivation.
\end{abstract}

Keywords: telecollaboration, multimodal interaction, intercultural competence, motivation, teacher training, tasks.

\section{Introduction}

Much has been written about telecollaboration projects and how they contribute to shape the development of communicative competence (Guth \& Helm, 2010; Canto, Jauregi \& Bergh, 2013), intercultural awareness (Belz \& Thorne, 2006; O’Dowd, 2007; Canto, Graaff, \& Jauregi, 2014) and motivation (Jauregi, Graaff, Bergh, \& Kriz, 2012) of those engaging in telecollaboration tasks (González-Lloret \& Ortega, 2014; Jauregi et al. 2011; O’Dowd \& Waire, 2009). But most of these studies report on experiences carried out at tertiary education (Pol, 2013). The question is whether these results are transferable to secondary education where

1. Utrecht University \& Fontys University of Applied Sciences, Netherlands; k.jauregi@uu.nl

2. TILA: Telecollaboration for Intercultural Language Acquisition (www.tilaproject.eu).

How to cite this article: Jauregi, J. (2015). Integrating telecollaboration for intercultural language acquisition at secondary education: lessons learned. In F. Helm, L. Bradley, M. Guarda, \& S. Thouësny (Eds), Critical CALL Proceedings of the 2015 EUROCALL Conference, Padova, Italy (pp. 268-273). Dublin: Research-publishing.net. http://dx.doi.org/10.14705/rpnet.2015.000344 
young pupils have to learn foreign languages in quite different circumstances. But very little is known about it.

The TILA project (Jauregi, Melchor-Couto, \& Vilar, 2013) originated from this very specific need and aimed at exploring how telecollaboration may affect language learning processes for communication, intercultural understanding and motivation of youngsters at secondary schools. One of the ambitions of TILA has been to design a model for sustainable integration of telecollaboration activities in blended pedagogical approaches at secondary education.

\section{Data and methodology}

837 learners, 300 student teachers and 48 teachers participated in different pilot experiences using synchronous (chat, videocommunication and $3 \mathrm{D}$ virtual worlds) and/or asynchronous (wikis, blogs and discussion forum) communication tools between November 2013 and June 2015. 55 tasks for different target languages, proficiency levels, interaction tools and communication constellations have been developed $^{3}$ for telecollaboration exchanges (Jauregi, 2015).

Pupils participated in dyadic or small group interactions either using the target language as lingua franca (a foreign language for those pupils collaborating in the exchanges) or in a tandem constellation, with pupils interacting with a native/ expert speaker of the target language, alternating languages (French pupils learning Spanish who communicate in French and in Spanish with Spanish pupils learning French). Although in the first pilot experiences most teachers preferred the tandem communication constellation ( $60 \%$ of all exchanges), in the follow up sessions the lingua franca constellation was the favourite one (72\%).

In the initial pilot experiences telecollaboration exchanges were organised at school, mostly in the computer lab, but as many technological problems were experienced with the school hardware and internet connections, and because of lack of privacy for pupils when conducting the conversations, in the follow up many of these exchanges were carried out quite successfully, from home by flipping pedagogies.

Data from surveys, recordings and interviews were gathered for our mixed method research approach to studying the effects of telecollaboration on youngsters at secondary schools.

3. Tasks are all available at the project site: www.tilaproject.eu. 


\section{Findings}

In the following, the main findings of the study will be presented focusing on the impact of telecollaboration on pupils' intercultural communicative competence and their motivation.

\subsection{The development of intercultural communicative competence}

Results on the analysis of chat logs and video communication recordings indicate that telecollaboration exchanges have a positive impact on pupils' intercultural communicative competence as pupils are provided with opportunities for spontaneous and authentic written and spoken communication with real peers. The telecollaboration tasks seemed to enhance intercultural competence and awareness as pupils engaged in conversations, exchanging their opinions on cultural similarities and differences, and reflected upon rich intercultural points that emerged in discourse. In this sense, tasks that are close to pupils' lives, where they can draw on their own experiences and opinions seem to work best in telecollaboration exchanges. Pupils were curious about other ways of organising lives, of doing things; they succeeded in showing openness and interest to know more about the Other and resorted to meta discursive conversational devices to clarify intercultural meaning (Kroon, Jauregi, \& Thije, 2015). An overall cooperative communication attitude seemed to prevail in the exchanges analysed.

It was observed that the various tools greatly differ in their communication affordances. Chat discourses were found to be quite fragmentary, highly task driven, with few instances where pupils truly engaged in topic co-creation and negotiation of meaning. Communication patterns in BigBlueButton (video communication platform), on the contrary, were far more complex, with pupils being more engaged in elaborating topics, in sharing personal experiences and in negotiating meaning. Because of the speakers' visual presence and the immediacy of spoken language, interactions in BigBlueButton seemed to be more conducive to enhancing intercultural openness curiosity and awareness (Tró Morató, 2015). The favourite interaction tool for telecollaboration exchanges was video communication (the open source BigBlueButton) both in the pilot (64\%) and the follow-up activities (83\%).

The differences in communication patterns that tools allow for should be seen as an opportunity for complementary pedagogic use. "A multi-modal telecollaboration approach offering tool options from virtual worlds and video communication to 
chat and forum is ideally suited for providing practice opportunities for all skills relevant in foreign language learning from reading and writing to listening and speaking" (Hoffstaedter \& Kohn, 2015, p. 5).

\subsection{Impact on motivation}

Within the TILA project, a study was carried out to explore the motivational dimension in secondary school pupils. A total of 202 foreign language learners from Spain, France, the Netherlands and the UK took part in this study between September 2013 and June 2015.

All participants completed an average of four foreign language interaction sessions either by written chat or by video communication. They worked in either lingua franca, tandem or mixed constellations. After every session, pupils completed a questionnaire including 21 items to be rated on a 5 point Likert scale. The data collected shows relevant findings that provide new insights to this particular field of research. Pupils that interacted via chat and in tandem constellations tend to show higher self-efficacy beliefs than those engaged in lingua franca exchanges using video communication. With regards to anxiety levels, they seem to decrease significantly as sessions progress. In addition, statistical differences were found according to the communication constellation used, with the lingua franca group presenting systematically the lowest anxiety scores. Similarly, the chat environment turned out to be less anxiety-provoking than the video communication platform. Regarding the use of webcam, participants seem to feel more at ease when their partner cannot see them through the webcam only during the first sessions.

\section{Conclusion}

TILA has pioneered a pedagogical innovative change in secondary education by looking at sustainable ways to integrate telecollaboration in foreign language curricula, while studying the effects that such exchanges may have on the intercultural communicative competence and motivation of pupils.

A wealth of data has been gathered for analysis. Initial results show that task-driven telecollaboration exchanges do have a positive impact in the development of intercultural communicative competence of pupils and on their motivation. Video communication seems to stimulate more complex discourse production than chat encounters and might be more useful for stimulating richer intercultural exchanges than chat. Yet, chat and lingua franca communication constellation seem to trigger 
less anxiety than video communication. Additional research will be needed to substantiate these findings.

\section{Acknowledgements}

We would like to thank the pupils and their teachers in the participating schools as well as the whole TILA community for their contribution to the TILA research team.

\section{References}

Belz, J., \& Thorne, S. (Eds.). (2006). Internet-mediated intercultural foreign language education. Boston: Thomson Heinle.

Canto, S., Graaff, de R., \& Jauregi, K. (2014). Collaborative tasks for negotiation of intercultural meaning in virtual worlds and video-web communication. In M. González-Lloret \& L. Ortega (Eds.), Technology and tasks: exploring technology-mediated TBLT. Amsterdam / Philadelphia: John Benjamins.

Canto, S., Jauregi, K., \& Bergh, van den H. (2013). Integrating cross-cultural interaction through video-communication and virtual worlds in foreign language teaching programs. Burden or added value? ReCALL, 25(1), 105-121. doi:10.1017/s0958344012000274

González-Lloret, M., \& Ortega, L. (Eds.). (2014). Technology-mediated TBLT: researching technology and tasks. Amsterdam: John Benjamin. doi:10.1075/tblt.6

Guth, S., \& Helm, F. (Eds.). (2010). Telecollaboration 2.0: language literacies and intercultural learning in the 21st century. Bern: Peter Lang.

Hoffstaedter, K., \& Kohn, K. (2015). Telecollaboration for intercultural foreign language conversations in secondary school contexts: task design and pedagogic implementation. In TILA Research Results on Telecollaboration. Retrieved from http://www.tilaproject.eu/ moodle/mod/page/view.php?id=1495

Jauregi, K. (2015). Task development for telecollaboration among youngsters. In Proceedings of the ANTWERP CALL 2015 Conference: Task design and CALL, 6-8 July 2015, Universitat Rovira i Virgili, Tarragona, Spain.

Jauregi, K., Canto, S., de Graaff, R., Koenraad, A., \& Moonen, M. (2011). Verbal interaction in Second Life: towards a pedagogic framework for task design. Computer Assisted Language Learning Journal, 24(1), 77-101. doi:10.1080/09588221.2010.538699

Jauregi, K., Graaff, de R., Bergh, van den H., \& Kriz, M. (2012). Native non-native speaker interactions through video-web communication, a clue for enhancing motivation. Computer Assisted Language Learning Journal, 25(1), 1-19. doi:10.1080/09588221.2011.582587

Jauregi, K., Melchor-Couto, S., \& Vilar, E. (2013). The European Project TILA. In L. Bradley $\&$ S. Thouësny (Eds.), 20 years of Eurocall: learning from the past looking to the future (pp. 123-129). Dublin: Research-publishing.net.. doi:10.14705/rpnet.2013.000149 
Kroon, L. v. d., Jauregi, K., \& Thije, J. ten. (2015). Telecollaboration in foreign language curricula: a case study on intercultural understanding during synchronous telecollaboration sessions through video communication. International Journal of Computer-Assisted Language Learning \& Teaching, 5(3), 20-41.

O'Dowd, R. (Ed.). (2007). Online intercultural exchange: an introduction for foreign language teachers. Clevedon: Multilingual Matters.

O’Dowd, R., \& Waire, P. (2009). Critical issues in telecollaborative task design. CALL Journal, 22(2), 173-188. doi:10.1080/09588220902778369

Pol, L. (2013). Telecollaboration in secondary education: an added value? Unpublished Master thesis. Utrecht University.

Tró Morató, T. (2015). Telecollaboration for intercultural language acquisition. Analysis of secondary education pupils' discourses in chat and videoconference format within the Telecollaboration for Intercultural Language Acquisition (TILA) framework. Unpublished Master Thesis. University of Girona. 


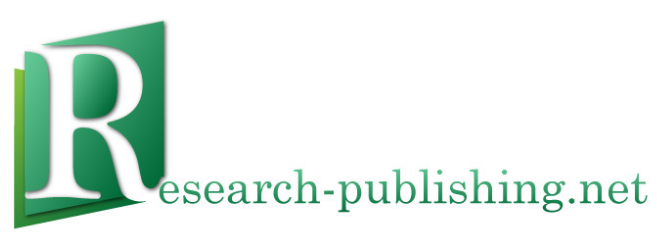

Published by Research-publishing.net, not-for-profit association Dublin, Ireland; info@research-publishing.net

(C) 2015 by Research-publishing.net (collective work)

(C) 2015 by Author (individual work)

Critical CALL - Proceedings of the 2015 EUROCALL Conference, Padova, Italy Edited by Francesca Helm, Linda Bradley, Marta Guarda, and Sylvie Thouësny

Rights: All articles in this collection are published under the Attribution-NonCommercial -NoDerivatives 4.0 International (CC BY-NC-ND 4.0) licence. Under this licence, the contents are freely available online (as PDF files) for anybody to read, download, copy, and redistribute provided that the author(s), editorial team, and publisher are properly cited. Commercial use and derivative works are, however, not permitted.

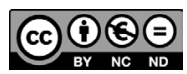

Disclaimer: Research-publishing.net does not take any responsibility for the content of the pages written by the authors of this book. The authors have recognised that the work described was not published before, or that it is not under consideration for publication elsewhere. While the information in this book are believed to be true and accurate on the date of its going to press, neither the editorial team, nor the publisher can accept any legal responsibility for any errors or omissions that may be made. The publisher makes no warranty, expressed or implied, with respect to the material contained herein. While Research-publishing.net is committed to publishing works of integrity, the words are the authors' alone.

Trademark notice: product or corporate names may be trademarks or registered trademarks, and are used only for identification and explanation without intent to infringe.

Copyrighted material: every effort has been made by the editorial team to trace copyright holders and to obtain their permission for the use of copyrighted material in this book. In the event of errors or omissions, please notify the publisher of any corrections that will need to be incorporated in future editions of this book.

Typeset by Research-publishing.net

Fonts used are licensed under a SIL Open Font License

ISBN13: 978-1-908416-28-5 (Paperback - Print on demand, black and white)

Print on demand technology is a high-quality, innovative and ecological printing method; with which the book is never 'out of stock' or 'out of print'.

ISBN13: 978-1-908416-29-2 (Ebook, PDF, colour)

ISBN13: 978-1-908416-30-8 (Ebook, EPUB, colour)

Legal deposit, Ireland: The National Library of Ireland, The Library of Trinity College, The Library of the University of Limerick, The Library of Dublin City University, The Library of NUI Cork, The Library of NUI Maynooth, The Library of University College Dublin, The Library of NUI Galway.

Legal deposit, United Kingdom: The British Library.

British Library Cataloguing-in-Publication Data.

A cataloguing record for this book is available from the British Library.

Legal deposit, France: Bibliothèque Nationale de France - Dépôt légal: décembre 2015. 